\title{
Indigenous Identity as Country: The "Ing" within Connecting, Caring, and Belonging
}

\author{
Jo Anne Rey
}

check for

updates

Citation: Rey, Jo Anne. 2021.

Indigenous Identity as Country: The

"Ing" within Connecting, Caring, and

Belonging. Genealogy 5: 48. https://

doi.org/10.3390/genealogy5020048

Received: 10 March 2021

Accepted: 28 April 2021

Published: 10 May 2021

Publisher's Note: MDPI stays neutral with regard to jurisdictional claims in published maps and institutional affiliations.

Copyright: (C) 2021 by the author Licensee MDPI, Basel, Switzerland. This article is an open access article distributed under the terms and conditions of the Creative Commons Attribution (CC BY) license (https:/ / creativecommons.org/licenses/by/ $4.0 /)$.
Department of Indigenous Studies, Macquarie University, Macquarie Park, NSW 2109, Australia; jo.rey@mq.edu.au

\begin{abstract}
Within the Australian Indigenous community, it is often said that Aboriginality is a verb. It is a "doing" word, not a noun. As such, identifying actively is at the heart of being Australian Aboriginal. Doing identification, rather than owning a label of identification, is critical to understanding the relationality that underpins Indigenous identity. It is the 'Ing' of relationality which acts as an interconnected web of presences (including people), places, and practices. When this web is ancestral, it marks our belonging. For Dharug, this is our "Country", our Dharug Ngurra. It is physical and metaphysical. It is also known as most of the Sydney basin, Australia. The agency that connects us, strengthens our caring, and generates our belonging helps us co-become as a Country. This paper engages the author's "Ing" as Ngurra through her connections to three sites, their presences, places and practices, that activate her belonging to/with the Dharug community: Brown's Waterhole, Blacktown Native Institution, and Yallomundee. Using undergraduate teaching experiences and a current post-doctoral research project for specific context, questions around the 'Ing' of being Indigenous as Country-in-the-city are raised, while the significance of changing relationships for custodial caring in a climate challenging reality are discussed.
\end{abstract}

Keywords: Dharug; Australian Aboriginal; Indigenous; Country; identity

\section{Introduce-“Ing"}

Internationally renowned ecologist, David Suzuki $(1997$, p. 8) provided some pertinent commentary that frames the place of this paper in the body of literature on Indigenous identity, community, and Country:

Just as the key to a species' survival in the natural world is its ability to adapt to local habitats, so the key to human survival will probably be the local community. If we can create vibrant, increasingly autonomous, and self-reliant local groupings of people that emphasize sharing, cooperation and living lightly on the Earth, we can avoid the fate warned of by Rachel Carson and the world scientists and restore the sacred balance of life.

Nearly one-quarter of a century later, this statement not only resonates but now calls stridently for us to respond, as we watch the demise of Earth's natural balances, increasing climate-changing devastations, and destructions of local habitats. On Dharug Ngurra, Country of the Dharug-speaking people, also known as most of cosmopolitan Sydney, in Australia, the focus is on the local: the presences, places and people, through our custodial Aboriginal ways, are answering that call. This is achieved through recognition of humanity's need to connect to places and presences (humans and other-than-humans) in order to care for the biodiversity on which we all depend, and with that caring, together build a sense of belonging (Rey 2019a, 2019b). I argue that the activism that underpins sustainable continuity for all is the "Ing" of agency.

To explain, within Australian Indigenous community, it is often said that Aboriginality is a verb. It is a "doing" word, not a noun, a "person, place or thing" word. As such, identifying actively is at the heart of being Australian Aboriginal. Doing identification, 
rather than owning a label of identification, is critical to understanding the relationality that underpins Indigenous identity. It is the "Ing" of relationality, our connect-Ing, care-Ing, and belong-Ing, which acts as an interconnected web of presences (including people), places, and practices. When this web is ancestral, it marks our belonging. For Dharug, this is our "Country", our Dharug Ngurra. It includes the agency that connects us, strengthens our caring, and generates our belonging so that in the process, we co-become as Country (Ngurra et al. 2019).

This paper engages the author's "Ing" as Ngurra through her connections to three sites, their presences, places, and practices, that activate her belonging to/with the Dharug community: Brown's Waterhole, Blacktown Native Institution, and Yellomundee. Using undergraduate teaching experiences and a current post-doctoral research project for specific context, questions around the 'Ing' of being Indigenous as Country-in-the-city are raised, while the significance of changing relationships for custodial caring in a climate challenging reality is discussed.

\section{Activate-Ing the Connections to Presences, Places and People}

According to Larsen and Johnson (2017), activism for sustainable futures involves coexistence. Activism is not only human agency, but place agency. Places attract us, call us to connect, and to care. In the mutuality of that relationship, we co-become and grow (Country et al. 2015). This can lead us to an ecological as well as a human sense of belonging. This mutual agency enables more-than-human be-Ings. As such, for this mutuality to arise, place-based, experiential learning is required. If we do not spend time in conscious engagement with Ngurra, with our other-than-humans, how can we establish more-than-human mutualities? For Aboriginal peoples, the underlying premise of existence is our interdependence, reliance on reciprocity, and not just between people, but between humans and other-than humans. For sustainable futures, we must connect and/or reconnect the 'disconnected people' (Steffensen 2020, p. 163). In the aftermath of the 2020 megafires across NSW and large areas of Australia, recognizing the 'call' for activism from Ngurra in our polluted, neglected cities is an imperative that cannot be ignored.

It was such a 'call', the need for activism through experiential, out on Country, conscious engagement with Ngurra, that underpinned the pedagogical framing for a first-year undergraduate Indigenous Studies unit, developed from the findings of my doctoral thesis (Rey 2019a, 2019b). When Country is a city, with approximately 5 million humans, how to reframe the colonizing learning that underpins mass education in this State (and more broadly across the continent) was front and centre of the unit development. Getting Indigenous and non-Indigenous, Australian, and international students to connect to Ngurra in the city was (and continues to be) the challenge.

Fortunately, Macquarie University is located in an area of Sydney, on WallumattagalDharug Country, that is not far from what today is called the Lane Cove River, and the Lane Cove National Park. This local habitat is a 20 min walk from the campus Library. As such, its proximity calls us to engage with the natural landscapes and ecologies that Ngurra provides-ones that are today scarce, as suburbia and urban development dominate. The opportunity, the call of local, proximate place to activate experiential learning is strident. My ancestral belonging to this Ngurra, and particularly, one waterhole, Brown's Waterhole, its resident colony of Bell Miner birds, screeching sulphur-crested cockatoos, parakeets, the grounded evidence of Aboriginal presences, could not be ignored. From Brown's Waterhole, the next step could be taken. Weaving across Dharug Ngurra are literally thousands of Aboriginal archaeological sites hidden from mainstream view for their protection (Attenbrow [2002] 2010). Hundreds of sites though are publicly accessible. Making these the pathways for students to engage with Ngurra, through their own selfselected experiences, based on fortnightly themes, carry the students into a journey of experiential and transformative learning that fosters a consciousness of the power and agency of place, an attentiveness to the presences there, the storying associated with those 
presences and places, and finally, an opportunity to question: why bother and what will our futures look like if we continue on the same path as before. The mentalities of colonization cannot continue. These experiences are supported by Dharug community members, who provide their own perspectives on each of the themes, as developed through their own learning journeys, their places of connection, their activism in caring, and their own ways of teaching and sharing through cultural practices. Whether that be through art, song, dance, weaving, carving, or ceremony, cultural continuity embedded in engagement with Ngurra reflects the continuing mutuality that is more-than-human across thousands of years. Just as community members share, reflect, actively engage, care for, and grow their sense of belonging, so more than 60 students commence that journey each semester. Across 14 weeks, they develop their conscious learning through their own connections, experiences, responses, reflections, and grow an enhanced sense of responsibility for their own activism into the future. They grow their "Ing".

Thus, while the doctoral research candidature was the first step in my personal activism with/in Dharug Ngurra, the resulting development of the first-year undergraduate Indigenous Studies unit was step two. In the process, I am activating my own deeper sense of connection, caring and belonging, as students' reflections and creative responses (poetry, videos and music) weave me into their connections and caring (Rey 2020), strengthening my belong-Ing. Eighteen months later, the next step in the journey opened.

\section{Broaden-Ing the Connecting, Caring and Belonging}

That next "Ing" step involves broadening my relationships with Ngurra as I undertake a three-year Macquarie University Fellowship in Indigenous Research (MUFIR) across three Dharug Ngurra sites, which commenced in September 2020. The sites include, firstly, Yellomundee- Shaw's Creek Aboriginal Place, on the Dyarubbin (Hawkesbury-Nepean) River at the foot of the Blue Mountains National Park. Secondly, the Blacktown Native Institution site (BNI, at Oakhurst) is included, and thirdly Brown's Waterhole, on the Lane Cove River. Each site is engaged through a variety of ways of knowing: the written records, oral/audio storying, and visual interpretations. In this opening year, the emphasis of connection has been through the written and visual knowledges.

Concerning the BNI site and Brown's Waterhole, my family storying involves my great, great grandmother, Ann Randall, who was institutionalized by her 'mother', Fanny (Brook and Kohen 1991), first as a little 6-year-old in the Female Orphans School at Parramatta in 1822. This was at the time First Fleet, African American convict John Randall senior disappears from the written records. Whether he was the father or grandfather of Ann is still conjectured. Later, she was transferred to the Black(s) Town Native Institution when it opened in 1825. Woven beyond the two places of institutionalization, Ann's storying continues because her Aunty/Mother/half-sister (depending on whose version of the genealogical storying is followed), Frances Randall married her second and final partner William Brown. The first was John Aiken, another African American, First Fleet convict and close friend of the Randall family. However, it was the descendants of Fanny and William Brown, the timber-getting family, that the waterhole is named after (Brook and Kohen 1991; Hawkins 1994; Kohen 2010). Thus, two of the three sites are directly woven into my direct lineage. Yellomundee, while not within my immediate heritage, is today the site of much re-activation of Dharug cultural practices, as is the BNI site for community, and so weaving the web of Dharug connection across Ngurra-as-city today cannot ignore the agency and leadership that Yellomundee is transmitting.

My "Ing" was sparked when I learned (as a 53-year-old woman) of Ann's existence. This was the profound connection that sparked my linking with local Dharug heritage. Her institutionalization at such a young age, in places where some children did not survive, sparked the drive to learn the colonial legacy driven by Governor Lachlan Macquarie, after who Macquarie University is shamedly named. Knowing activated me to move beyond understanding my place of belonging as simply the 'city of Sydney'. Instead, these presences, places, people, and practices are now far more recognizable as Dharug 
Ngurra, than a cartographically mapped landscape principally derived and divided up by early British colonizers. Learning of my Dharug heritage, as well as of my First Fleet convict ancestors, and their relationships with Ngurra and the Dharug people in the late 18th and 19th centuries, drove a deep motivation to learn, engage, connect, care, and belong beyond anything I have ever experienced before. The connect-“Ing" weaves the co-become-"Ing" through our stories with the presences, the places, the people, and the practices. We transform, and we understand a deeper purpose in our continuity. Activation transforms into activism.

\section{Be-“Ing”: Re-weaving of Ngurra}

Storying, thus, is the essence of 'Ing'. As Gottschall (2012) notes, we are the storytelling animal. Whether that storying be rendered through oral, written, artistic, kinaesthetic, olfactory, or somatosensory (touch) means is irrelevant for connection. It is the storying that underpins our relationship with the presences and places, people and practices which activate and transform us-or not. As such, Steffensen (2020) recognition that it in the disconnections, the lack of relationship with Ngurra, where the damage is done. If people are disconnected then the caring is not activated and storying of connection does not happen. Thus activism, in essence, involves moving towards storying, sharing, respect and reciprocity. It is only storying from traditional owners of Dharug Ngurra who can bring an authentic voice to the literature because they have the continuing connections to presences, places and peoples of that Country. Without activism, there can be no understanding, no relationship, no connecting, no caring and no memory, thus no authentic storying. It is not about human-centricity, but rather the significance of thousands of years of storying, the songlines (Neale 2020), and song spirals (Gay'wu Group of Women 2019), the Dreaming tracks (Griffiths 2018) and reading Country (Benterrak et al. 2014). It is about time, be-"Ing" and being attentively present (Plumwood 2001).

Due to colonization, and the associated effects of genocidal intent (Tatz 2017), dispossession of Ngurra, disruption of Law /Lore and language, undermined Dharug voice. That disempowerment has until recently rendered Ngurra as an absent Presence, interpreted and storied by others as a globalized, cosmopolitan, urbanized, city. As noted by Graham and Pottage (2011, p. 2), current law perpetuates

... a particular mindset, a paradigm that detaches people from place, viewing the world not as a network of relationships, but as two separate spheres: culture and nature. This paradigm is, however, in crisis ...

Following Kuhn (1996) theories involving paradigm shifts which occur only when a paradigm becomes dysfunctional, Graham and Pottage (2011) suggest that the changes required involve moving from anthropocentric, European cultural mindsets, and supporting bringing Indigenous perspectives to discussions around conceptualization of 'property' and law.

As such, Dharug activations, Dharug voices, Dharug storying, Dharug weaving connections, culture, caring across Ngurra-as-Sydney offer alternatives to the mindset that positions Ngurra as only a city devoid of storying that entwines first owners' culture with nature. In recent times, at least since the fight for Native Title (2004), which was withdrawn under legal advice, activism is re-weaving Ngurra across Sydney. Local Dharug storying and activism now involve many community members. There is a whole Dharug community activating Ngurra through storying and their continuing connections with the presences, places, and practices. With increased social media use, activisms (as evidenced on various community sites) engage thousands of people and Dharug community numbers are growing. Beyond Rey (2019a, 2019b, 2020) and Rey and Harrison (2018) doctoral and post-doctoral research, activations through the written records include (but are not limited to): Seymour and Watson (2019); Watson et al. (2014); Harrison et al. (2016); Tobin (1999); Tobin (2011, 2014); Tobin (2013); Ngurra et al. (2019), and Foley (2000, $2001,2003,2007,2020)$. Several organizations and groups are also actively engaging with community and Ngurra's presences, places, and practices. These include (but are not 
limited to) the Dharug Strategic Management Group (DSMG 2020), who are the trustees of the Blacktown Native Institution site; the Dharug Ngurra Aboriginal Corporation (DNAC) at Seven Hills; the Dharug Custodians Aboriginal Corporation (DCAC); the Burbaga Aboriginal Corporation; the Boorooberongal Elders Aboriginal Corporation; and Muru Mittigar. Overall, the activism of community has arisen as a direct result of the recognition that caring for Country, community and culture cannot continue without that care-"Ing", connect-"Ing" and belong-“Ing".

In the following segments, specific storying as activism will be centered on the three sites: Yellomundee, BNI and Brown's Waterhole. I use the term 'storying up' as an expression of activation through Ngurra across the sites, and activism through the research and by filming. Storying Country responds to the relational reciprocity that underpins sustainable, localized futures. Recognizing this is critical to shifting the anthropocentric mindset that has set in play the disasters of climate change that we are witnessing across the globe.

\section{Yellomundee-Storying Up Ngurra through Research and Filming}

Yellomundee Aboriginal Place (see Figure 1) is a site named after Dharug Boorooberongal Koradji (Elder and spirit) man, Yellahmiendi (Karskens et al. 2021). It has many stories woven together-ancient, Aboriginal, colonial, contemporary and futures (Karskens et al. 2019; Ngurra et al. 2019; Stockton and Knox 2019). It sits within an area currently named the Yellomundee Regional Park, near Shaw's Creek, and beside the Dyarubbin (HawkesburyNepean River) in far western Sydney at the foot of the Blue Mountains. Nearby are highly significant archaeological Aboriginal sites, K1 and K2 (Karskens 2020; Stockton and Knox 2019; Stockton and Merriman 2009).

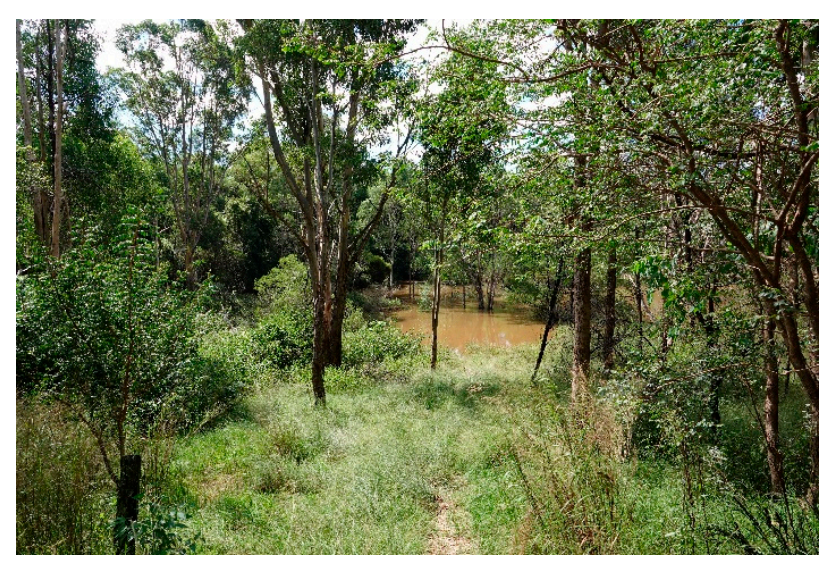

Figure 1. Yellomundee Aboriginal Place, Shaw's Creek. (With permission - Mark Parry (Photographer)).

Further, much recent interest in the area has been aroused with the finding of Reverend John McGarvie's 1825 list of Aboriginal Names for sites along the Dyarubbin river (Karskens 2020; Karskens et al. 2019, 2021). However, colonially, Shaw's Creek is named after the convict Shaw family, who settled and had their farm on the site (Karskens 2020).

Thus, naming and storying are interwoven, with each affecting identities of place, of people, the other-than humans, and the way relationships can be formed with the presences inhabiting there. As Karskens (2020, p. 210) notes in relation to the vicinity:

Hunting provided some common ground with Aboriginal warriors. After 1788, Aboriginal and white men set out on hunting trips together, on foot. The warriors carried spears, woomeras, and axes, while the foresters were sometimes armed with muskets, but more often they only used their savage, muscular dogs to run down the kangaroos. 
K1 holds an engraving of a dog, described by some as a 'kangaroo dog' (Karskens 2020, p. 210).

In recent years, important activation has taken place, through the Yanama Budyari Gumada research collective, implementing an Indigenous fire burn workshop, culture camps, and general Dharug community gatherings (Ngurra et al. 2019). As Karskens (2020, p. 523) notes:

... in 2014, part of Yellomundee Regional Park was gazetted as the Shaw's Creek Aboriginal Place, in recognition of both its Aboriginal significance and the ongoing connection that local Aboriginal people have with this area.

For the Macquarie University students involved in the current phase of this MUFIR, 2020 research project at the (Yellomundee) Shaw's Creek Aboriginal Place, they are immediately made conscious of places, presences, and human relationships woven together, simply by the naming. However, later, as they work towards activating their own new relationship with Ngurra there, it is expected that this activism can be challenging, exciting, and/or intimidating, depending on the newcomer's existing paradigm, their knowledges, prejudices, and self-storying. As Larsen and Johnson (2017, p. 199) remind us,

The agency of place upon humankind is indelibly spiritual. It is a transformative passage not through an abstract liminal phase or contact zone but through the call of place toward mutual recognition and reciprocal guardianship of the well-being of the many relationships within that place.

Activating a relationship with the site, one that engages Aboriginal protocols, will involve a completely different conscious framing of this place. Based on previous undergraduate research students' responses through the Macquarie University Indigenous Studies department unit ABST1020, this MUFIR research has the potential to be transformative. As they engage with opening themselves to the various presences in place, Macquarie University Bachelor of Screen students will be working to document the process of their engagement, their recognition, and ways of connection through film as part of their Professional and Community Engagement (PACE) program (PACE 2017). At the same time, they will be filmed, for a second layer of recording, to establish what processes of learning, identifying and relational negotiations they undertake. Learning through the presences in place at the site opens pedagogical opportunities and better understanding of its importance for deep experiential and transformative learning (Blake et al. 2013; Illeris 2014; Jackson et al. 2013).

As Larsen and Johnson (2017) show, place creates, speaks, and teaches. When we consider Dharug Ngurra's activism within broader community gatherings, the fire, the dance, ceremony and Ancestors' engravings, the power and agency of this Yellahmiendi place, bring and have brought significant opportunities to activate change. Lemire (2018, p. 1) recognizes this through her dance-as-research at Yallomundee:

Darug Ngurra guides our research and choreographs our dance and I attend to this entanglement of human and non-human (more-than-human) dancers in the place of the dance circle. It is the spinning with the rake-o, the 'shake a leg' with the lantana, raising your arms with the smoke, or stomping with the dirt that nurtures place. In the space of the dance circle, to dance is to care as Country. Through our mimicry of the tyirri tyirri [willie wagtail], marayong [emu], pipytere [hawk], or buru [kangaroo], we attend to the affective, embodied, more-than-human practice of co-becoming; a healing of ourselves in and as Country.

Larsen and Johnson (2017, p. 202) explain,

Humankind is very good at forgetting its interdependencies with others, choosing not to live in life-supporting ways and imposing its sense of mastery on the world. Place orients us, again and again, to our interconnectedness with human and non-human others in the relationships of Creation, our being-together-in-place. 
As such, this current research-as-activation through Ngurra potentially opens students to future reciprocal activism by caring for Ngurra through a greater consciousness of the role that relationships with presences, places, and people can have for sustainable futures.

\section{Blacktown Native Institution (BNI) Site-Storying up Ngurra through Research and Filming}

The second site for activation through the MUFIR research project involves the BNI site on the corner of Richmond and Rooty Hill Roads, at Oakhurst in western Sydney (see Figure 2 below). Again, the storying of the site crosses Dharug and colonial heritages, and it also includes my own family's heritage, as mentioned earlier.

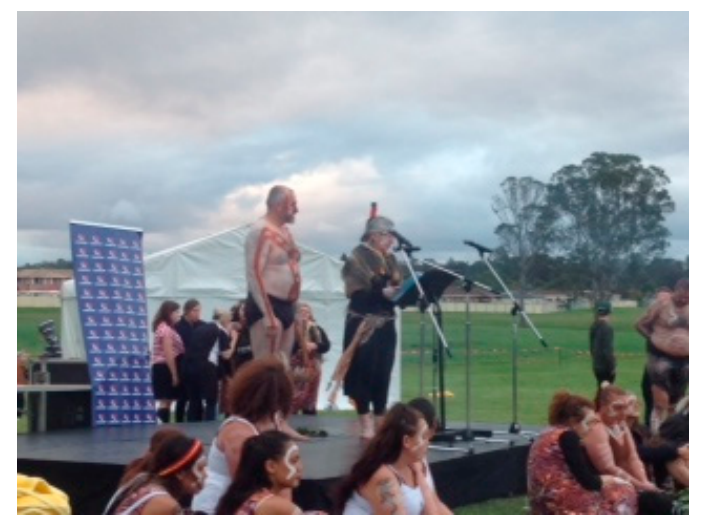

Figure 2. Image: Blacktown Native Institution site-Return-“Ing” to Dharug Custodianship, 13th October, 2018 Image: J. Rey.

In this instance, Ngurra's form is embedded in the current urbanized landscape that has spread since colonization. The archaeological remnants of the original building that opened in 1825 arise from the second phase of Governor Lachlan Macquarie's ambition and the series of influential missionaries' "civilizing" intent. This took place after the initial attempt at the Parramatta Native Institution failed (Brook and Kohen 1991; Norman-Hill 2020). The site was selected, located, and constructed as a direct result of local Dharug community presence, as Nurragingy and Colebee's land grant of 1819 was located nearby, and proximate to the silcrete ridge, today known as Stonecutter's Ridge, that had been central to axe making for many millennia. It is reasonable to suggest that additional factors that would have facilitated construction included the availability of water, as Bells Creek (as it is known today) crosses the site, the presence of Cumberland Plain forest providing suitable building timbers and its gently sloping terrain. Additionally, it was situated on the already established road between Parramatta, established in 1788, and Richmond, established in 1810 (1820s History of Aboriginal Sydney n.d.).

However, before 1788, the plains around Eastern Creek and South Creek were home to the Warrawarry and Wianamatta Dharug clans (Dharug Clans: History of Aboriginal Sydney n.d.). The area is recognized as being "immensely productive" for Dharug people, with abundant numbers of fauna (NSW Department of Planning, Industry and Environment 2011). The Dharug population across the Cumberland Plain can be evidenced through the thousands of Aboriginal sites recorded across Dharug Ngurra (Attenbrow [2002] 2010). Important presences included grassy woodlands, with kangaroo and wallaby grass still surviving. Trees of the area included Rough Barked Apple, Narrow-Leaved Ironbark, Broad-Leaved Ironbark, Grey Box, Scribbly Gum, and Forest Red Gum. Kangaroos, wallabies, emus, and possums would have been amongst many other-than-human presences hunted. The landscape and animals would have been nurtured through fire. Birdlife included Hooded Robin, Brown Treecreeper, Speckled Warbler and Diamond Firetail. However, by 1792, agricultural pursuits were under way in western Sydney (Birds in Backyards n.d.). As noted in governmental recovery plans for the Cumberland Plain (NSW Department of Planning, Industry and Environment 2011, p. 4): 
Clearing and fragmentation have had a profound effect on the fauna of the Cumberland Plain. Many mammal species declined to extinction in the decades after settlement. While many mammals persist in a small number of larger remnants, few exist in any number in western Sydney ...

Thus, today's storying and caring for the BNI site involves activism that is reclaiming Dharug voice, Dharug presence and Dharug custodianship, not only of the immediate physical site, but also across the broader physical, political, and spiritual dimensions of Ngurra. Stewardship, as active continue-Ing connect-Ing, care-Ing and belong-Ing, responds to the recognized primacy of reciprocity which lies at the heart of relational wellbeing for humans as well as other-than-humans. Reciprocal caring always has been and always will be the foundation of Aboriginal Law/Lore (Graham 2014). As such, the basic precepts of Aboriginal worldview recognize that the Law resides in the land and therefore the best way to achieve strategic continuity is localized caring for the land. Caring for the land through the BNI site is thus strategically supportive of Dharug cultural continuity.

Today's context of the BNI site is both a product of previous activism and the impetus for future activism, Previous activism, through many years of community pressure and then 5 years of committee negotiations, led to the return of the site, in October 2018, to Dharug community - the first land ever to have been returned by the State government (Landcom). Concomitantly, returning the land has activated efforts to regenerate the site with grasses and other flora for the benefit of remnant fauna that survive in today's urbanization. Bringing the site back into the stewardship of Dharug community gives a place for continuing cultural practice, ceremony, and spirituality through memorialization of those that suffered at the hands of colonizing authorities. Transgenerational story-Ing feeds future well-being and promotes future activism.

While the MUFIR research project aims to engage the site methodologically in a similar manner as at (Yellomundee) Shaw's Creek Aboriginal Place, the form, the context, and the group of students filming their relationship with the site differ. As such, the storying will change.

\section{Brown's Waterhole (Lane Cove National Park) Site-Storying up Ngurra through Research and Filming}

As mentioned earlier, I also have personal family connections with this Brown's Waterhole site (See Figure 3 below). Additionally, it is proximate to Macquarie University, which allows frequent and diverse engagement opportunities, as well as encouraging closer connections between the institution and localized caring to be activated. Further, the site, being situated in the Lane Cove National Park, means that storying involving care by local and state government bodies includes publicly available statements of intent and documentation around priorities, protections, and practices. As such, weaving the various perspectives brings a complexity to the identity of Brown's waterhole.

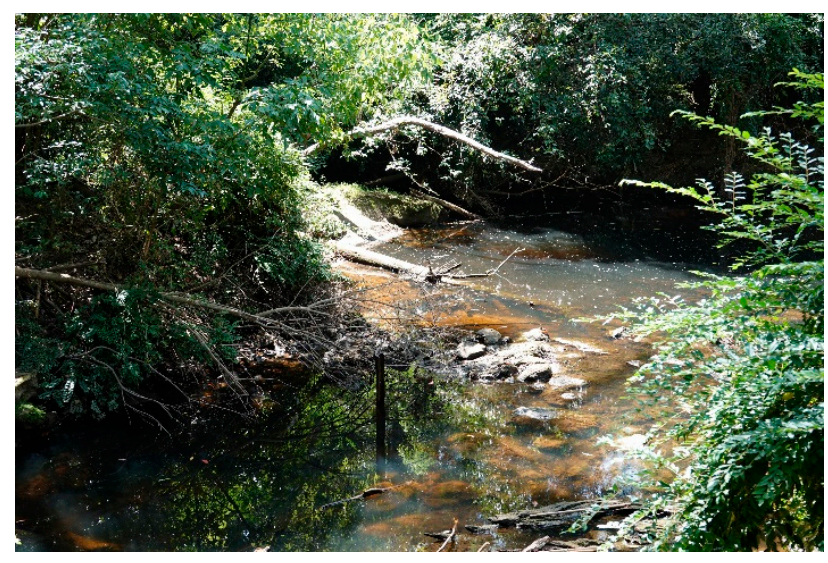

Figure 3. Image: Brown's Waterhole-Image: J. Rey, 2018. 
Historically, it has a record of sadness, including a drowning accident (Girl Drowned 1933), a suicide (Terry's Creek Tragedy: Sad End of a Sydney Architect 1907), and local fights over proposed placement of a cemetery (Topics 1892) and a slaughterhouse within its vicinity (Proposed Slaughter House for Carlingford 1892). Geographically, it is the meeting place of two waterways, what is now called Lane Cove (Turrumburra) River and Terry's Creek. From Dharug perspectives, it is a boundary place between D/Turramurrigal and Wallumattagal clans. According to current governance, it is a meeting place of three local shire councils-Ryde, Kuringai and Hornsby. Within the river itself, its liminality between creek and river, in the form of a waterhole, transitions according to the season, pollution, and its inhabitants. Such a boundary place reflects neglect. The presence of sadness at this place activated my curiosity and prompted questions. Was it only me that responds to this place in this way? Do others see it as a neglected place? What are the stories attached to this place? What was this place to local Dharug people, prior to early colonization? How can it be healed?

It was the final question that provoked the "Ing" and activated my search for answers, knowledge, and reconnection with the site through the post-doctoral research program. Already She (Ngurra as the waterhole) is providing and provoking interesting responses from the various human and other-than-human participants in Her storying. Drone footage provides different perspectives on Her form, relationships with surrounds, as well as the prevalence of weeds, stormwater, and rubbish. The alteration of Her form by the construction of a causeway so that vehicular and pedestrians can cross the waterway has an enormous impact on the flows and agency (human/other-than-human) of the place. Particularly cyclists, who speed down from the neighbouring areas of Turrumurra and Marsfield, and in their hurry and pre-occupation, do not recognize Her identity, her stories, or her life as they pelt past. They are disconnected and only use Her as a bridge between places they are leaving and places they are going to. This utilitarian, human-centric relationship limits Her agency, diminishes the place which is central for the inhabitants: the sulphur-crested cockatoos, bell miners, "Edgy Eddy" — the resident Eastern Water Dragon, or the black snake we met when visiting one day. This black snake was hiding amongst the weedy undergrowth shrouding the bank below the castor oil plants that proliferate there. Is she the current custodian of place, descendant of the black diamond snake who wrapped Herself around a young man's foot back in October, 1906 (An Uncanny Experience 1906)? Bringing the past into present entwines the storying into a non-lineal relationship, resonant of Barad (2010) hauntologies, producing time/space/matter-Ings.

Caring for Ngurra at Brown's Waterhole requires the recognition, respect and the acceptance of responsibility for the relationship we have when we rely on Her well-being for our own. It is not sufficient for neighbouring land-title holders to say, well I do not personally own that land, therefore I do not have to be responsible for looking after it. When the flames lick the fence-lines, it becomes abundantly clear that Western law is inadequate to sustain the owner's well-being, and a paradigm shift is required. Recognizing reciprocity within relationships is fundamental to Aboriginal Law/Lore (Graham 2014) and it is the primacy underpinning the Law/Lore of 'always has been, always will be' that makes the state laws ephemeral in comparison. As such, Country and identity are interwoven through the agency of connection, caring and belonging. Within that agency is the "Ing" of Indigenous continuity.

\section{Conclude-Ing: As Future-Ing}

As has been argued in this paper, the essence of the web of interconnections that is at the heart of County entwines the consciousness of identifying as an agency, not as a label. As David Suzuki called out, it will be the local activations that will sustain continuity. Underpinning local is connecting, caring, and belonging. It is only through a sense of disconnection that disjunctures evolve. Instead of belonging, today in the cities, we see long-Ing to be, a yearn-Ing to belong. Broken relationships strike at the heart of human well-being, producing suffering in the forms of loneliness, mental and emotional 
unwellness, which can result in and be evidenced by behavioural destructiveness. Those relationships involve, not only, human-to-human beings. As Victor Steffensen (2020) argues, disconnected people are at the heart of the problem. The British exiles, the convicts and authorities who arrived on the shores of Dharug and Dharawal Ngurra in 1788 and later were damaged, disconnected and ignorant. They suffered loneliness, mental and emotional unwellness, and an uncaring for Country, so that landscapes were only there to be utilized: ancient trees slaughtered to make bridges (Hawkins 1994); rivers polluted for business and industries (Scott 2017); local peoples abused, imprisoned, and forced to be disconnected too. In this paper, I have argued that it is activism, the "Ing", that does the work of connecting, the caring and the belonging to Ngurra, and requires relational reciprocity and responsibility, that is, a return to Indigenous Law/Lore, the primacy and foundational way for sustainability. As mega-fires, pollution, and climate change enfold us in their agency, it will only take a re-vision to offer future-Ing.

Ngurra, yanama budyari gumada,

Walk-Ing good spirit Ngurra.

Funding: This research received no external funding.

Institutional Review Board Statement: The study was conducted according to the guidelines of the Declaration of Helsinki, and approved by the Institutional Review Board (or Ethics Committee) of MACQUARIE UNIVERSITY (protocol code National Statement on Ethical Conduct in Human Research (2007-Updated 2018) (the National Statement). Dated: 15 December 2020).

Informed Consent Statement: Informed consent was obtained from all subjects involved in the study.

Conflicts of Interest: The author declares no conflict of interest.

\section{References}

1820s History of Aboriginal Sydney. n.d. Available online: https://www.historyofaboriginalsydney.edu.au/west/1820s (accessed on 6 June 2020).

An Uncanny Experience. 1906. Newspaper Article. Available online: http:/ /nla.gov.au/nla.news-article85942536 (accessed on 5 February 2021).

Attenbrow, Val. 2010. Sydney's Aboriginal Past: Investigating the Archaeological and Historical Records/Val Attenbrow. Sydney: UNSW Press. First published 2002.

Barad, Karen. 2010. Quantum Entanglements and Hauntological Relations of Inheritance: Dis/continuities, SpaceTime Enfoldings, and Justice-to-Come. Derrida Today 3: 240-68. [CrossRef]

Benterrak, Krim, Stephen Muecke, Paddy Roe, Ray Keogh, and Joe (Nangan) Butcher. 2014. Reading the Country: An Introduction to Nomadology. Edited by E. M. Lohe. Fremantle: Fremantle Arts Centre Press.

Birds in Backyards. n.d. Available online: https:/ / www.birdsinbackyards.net/content/plantlist/Blacktown-City-Plant-List (accessed on 3 May 2021).

Blake, Joanna, Stephen Sterling, and Ivor Goodson. 2013. Transformative Learning for a Sustainable FutureAn Exploration of Pedagogies for Change at an Alternative College. Sustainability 5: 5347-72. [CrossRef]

Brook, Jack, and James Kohen. 1991. The Parramatta Native Institution and the Black Town: A History. Kensington: New South Wales University Press.

Country, Bawaka, Sarah Wright, Sandie Suchet-Pearson, Kate Lloyd, Laklak Burarrwanga, Ritjilili Ganambarr, Merrkiyawuy Ganambarr-Stubbs, Banbapuy Ganambarr, Djawundil Maymuru, and Jill Sweeney. 2015. Co-Becoming Bawaka: Towards a Relational Understanding of Place/Space. Progress in Human Geography. Available online: http://phg.sagepub.com/content/ early/2015/06/30/0309132515589437.abstract (accessed on 3 May 2021).

Dharug Clans: History of Aboriginal Sydney. n.d. Available online: https://www.historyofaboriginalsydney.edu.au/west/darug-clans (accessed on 3 May 2021).

DSMG. 2020. Dharug Strategic Management Group. Available online: https:/ /www.dsmg.org.au (accessed on 3 May 2021).

Foley, Dennis. 2000. Too white to be black, too black to be white. Social Alternatives 19: 44-49.

Foley, Dennis. 2001. Repossession of Our Spirit: Traditional Owners of Northern Sydney. Canberra: Aboriginal History Incorporated.

Foley, Dennis. 2003. Indigenous epistemology and Indigenous standpoint theory. Social Alternatives 22: 44-52.

Foley, Dennis. 2007. What has native title done to the urban Koori in New South Wales who is also a traditional custodian? Social Effects of Native Title: Recognition, Translation, Coexistence. pp. 167-83. Available online: http://press.anu.edu.au/wp-content/ uploads /2011/05/whole_book28.pdf\#page=179 (accessed on 3 May 2021). 
Foley, Dennis. 2020. What the Colonists Never Knew: A History of Aboriginal Sydney, 1st ed. Canberra: National Museum of Australia Press.

Gale v Minister for Land and Water Conservation for the State of New South Wales. 2004. Available online: https://www.jstor.org/stable/26 452467 ?seq=1 (accessed on 3 May 2021).

Gay'wu Group of Women. 2019. Songspirals: Sharing Women's Wisdom of Country Through Songlines. Sydney: Allen \& Unwin.

Girl Drowned. 1933. Newspaper Article. Available online: http://nla.gov.au/nla.news-article107806547 (accessed on 5 February 2021).

Gottschall, Jonathon. 2012. The Storytelling Animal: How Stories Make Us Human. New York: Houghton Mifflin Harcourt.

Graham, Mary. 2014. Aboriginal notions of relationality and positionalism: A reply to Weber. Global Discourse 4: 17-22. [CrossRef]

Graham, Nicole, and Alain Pottage. 2011. Lawscape: Property, Environment, Law. Abingdon: Routledge.

Griffiths, Bill. 2018. Deep Time Dreaming: Uncovering Ancient Australia. Melbourne: Black Inc.

Harrison, Neil, Susan Page, and Leanne Tobin. 2016. Art Has a Place: Country as a Teacher in the City. Educational Philosophy and Theory 48: 1321-35. [CrossRef]

Hawkins, Ralph. 1994. The Convict Timbergetters of Pennant Hills: A history \& Biographical Register. Hornsby: Hornsby Shire Historical Society Inc.

Illeris, Knud. 2014. Transformative Learning and Identity. Journal of Transformative Education 12: 148-63. [CrossRef]

Jackson, Debra, Tamara Power, Juanita Sherwood, and Lynore Geia. 2013. Amazingly resilient Indigenous people! Using transformative learning to facilitate positive student engagement with sensitive material. Contemporary Nurse 46: 105-12. [CrossRef] [PubMed]

Karskens, Grace, Georgia Burnett, and Shawn Ross. 2019. Traces in a Lost Landscape: Aboriginal archaeological sites, Dyarubbin/Nepean River and contiguous areas, NSW, Australia (Data Paper). In Internet Archaeology. [CrossRef]

Karskens, Grace, Leanne Mulgo Watson, Erin Wilkins, Jasmine Seymour, and Rhiannon Wright. 2021. The Dyarubbin Project: Aboriginal History, Culture and Places on the Hawkesbury River. Dictionary of Sydney. Available online: https://dictionaryofsydney.org/ artefact/real_secret_river_dyarubbin_project (accessed on 3 May 2021).

Karskens, Grace. 2020. People of the River: Lost Worlds of Early Australia. Sydney: Allen and Unwin.

Kohen, James. 2010. African Connections: The Descendants of John Randall, John Martin, John Aiken, William Thomas and Thomas Corncrake (Conquit). Darug Tribal Aboriginal Corporation: Seven Hills.

Kuhn, Thomas. 1996. The Structure Of Scientific Revolutions. Chicago: University of Chicago Press.

Larsen, Soren Christiansen, and Jay Johnson. 2017. Being Together in Place-Indigenous Coexistence in a More Than Human World. Minneapolis: University of Minnesota Press.

Lemire, Jessica. 2018. Dancing up Darug: Performing Caring as Country in Semi-Urban Yarramundi, Sydney. Bachelor dissertation, Newcastle University, Newcastle, NSW, Australia; p. 1.

Neale, Margo. 2020. Songlines: The Power and Promise. Port Melbourne: Thames \& Hudson Australia Pty Ltd.

Ngurra, Dharug, Lexodious Dadd, Paul Glass, Rebecca Scott, Marnie Graham, Sarah Judge, Paul Hodge, and Sandie Suchet-Pearson. 2019. Yanama budyari gumada: Reframing the urban to care as Darug Country in western Sydney. Australian Geographer 50: 279-93. [CrossRef]

Norman-Hill, Rosemary. 2020. Reclaiming Darug History: Revealing the Truths about Settlement on Darug Ngurra through the Lens of an Australian Aboriginal Historical Research Methodology. (Phd.). Southern Cross. Available online: https://researchportal.scu. edu.au/discovery/delivery /61SCU_INST:ResearchRepository/1276606940002368?l\#1376606930002368 (accessed on 3 May 2021).

NSW Department of Planning, Industry and Environment. 2011. Cumberland Plain Recovery Plan. Available online: https: / / www.environment.nsw.gov.au/- /media/OEH/Corporate-Site/Documents / Animals-and-plants/Recovery-plans / cumberland-plain-recovery-plan-100501.pdf (accessed on 3 May 2021).

Plumwood, Val. 2001. Nature as Agency and the Prospects for a Progressive Naturalism. Capitalism Nature Socialism 12: 3-32. [CrossRef]

Proposed Slaughter House for Carlingford. 1892. From National Library of Australia. Available online: http:/ /nla.gov.au/nla.newsarticle86271023 (accessed on 5 February 2021).

Rey, Jo, and Neil Harrison. 2018. Sydney as an Indigenous place: “Goanna walking" brings people together. AlterNative: An International Journal of Indigenous Peoples 14: 81-89. [CrossRef]

Rey, Jo. 2019a. Country Tracking Voices: Dharug Women's Perspectives on Presences, Places and Practices. Doctorate dissertation, Macquarie University, North Ryde, Sydney, Australia.

Rey, Jo. 2019b. Dharug Custodial Leadership: Uncovering Country in the City. World Indigenous Nations Higher Education Journal 1: 56-66.

Rey, Jo. 2020. Weaving City Learnings into Country Futures. In Indigenous Futures and Learnings Taking Place. Edited by L. Lopez Lopez and G. Coella. Melbourne: Routledge, pp. 10-36.

Scott, Brian. 2017. The Business of the Lane Cove River from 1788. Lane Cove: Brian A.

Seymour, Jasmine, and Leanne Mulgo Watson. 2019. Cooee Mittigar: A Story on Darug Songlines. Broome: Magabala Books.

Steffensen, Victor. 2020. Fire Country: How Indigenous Fire Management Could Help Save Australia. Richmond: Hardie Grant Travel.

Stockton, Eugene, and John Merriman. 2009. Blue Mountains Dreaming: The Aboriginal heritage, 2nd ed. Lawson: Blue Mountain Education and Research Trust.

Stockton, Eugene, and Kelvin Knox. 2019. Aboriginal Heritage of the Blue Mountains: Recent Research and Reflections. Lawson: Blue Mountain Education \& Research Trust.

Suzuki, David. 1997. The Sacred Balance: Rediscovering Our Place in Nature. St Leonards: Allen \& Unwin. 
Tatz, Colin. 2017. Australia's Unthinkable Genocide. Bloomington: Xlibris.

Terry's Creek Tragedy: Sad End of a Sydney Architect. 1907. Newspaper Article. Available online: http://nla.gov.au/nla.news-article8 6155905 (accessed on 5 February 2021).

Tobin, Christopher. 1999. The Dharug Story: Our local history. In An Aboriginal History of Western Sydney from 1788, 2nd ed. Glenbrook: Chris Tobin.

Tobin, Jacinta. 2013. Learn Darug_Place Based Story. Available online: http:/ /learndarug.com/about-2/ (accessed on 3 May 2021).

Tobin, Leanne. 2011. Warraburra Healing (Naa Nora). In Acrylic. Springwood: Leanne Tobin.

Tobin, Leanne. 2014. Learn Darug-Place Based Mural. Available online: http://learndarug.com/2014/01/03/mural-project/ (accessed on 3 May 2021)

Topics. 1892. Available online: http:/ / nla.gov.au/nla.news-article86267673 (accessed on 5 February 2021).

Watson, Edna, Wes Marne, and Krystal Watson. 2014. Our Place: Aboriginal Stories on Country-Guringai and Darug. Available online: http:/ / www.hornsby.nsw.gov.au/community/coummunity-services/aboriginal-services (accessed on 14 October 2014) 